\title{
Khazanah
}

\section{JOHN AUSTIN}

Legal positivism is the leading doctrine about the nature of law. Its proponents insist that a realistic understanding of law must respect a dlstinction between law as it in fact is and law as we would like it to be.

David Dyzenhaus: Why Positivism is Authoritarian

Tidak ada yang menyangkal bahwa John Austin adalah penganjur dan pembela mazhab positivisme hukum. Lebih tepatnya, Austin dianggap sebagai pionir mazhab positivisme analitik, yaitu versi positivisme kontemporer yang mengklaim bahwa hukum yang sebenarnya adalah yang mewujud dalam praktik, bukan mengkonstruksi suatu konsep hukum pada tataran normatif dan idealisme politik semata. Dengan paham positivisme hukum ini Austin menjauhkan hukum dari basis dan penilaian subjektif yang dinilainya abstrak seperti moral dan etika, bahkan agama. Hukum harus bersumber dari sesuatu yang nyata dan ia menemukannya pada apa yang ia sebut sebagai 'sovereign' (daulat atau kuasa) yang bisa berwujud kuasa monarki seperti raja atau kuasa demokratis semisal parlemen. Sesuatu disebut hukum, bukan karena penilaian subjektif bahwa sesuatu itu bersifat baik atau buruk, melainkan karena berasal atau diproduksi oleh 'sovereign'. Atas semua klaimnya itu Austin mengatakan sebagai berikut: "the existence of law is one thing; its merit or demerit is another".

Positivisme hukum kemudian menjadi sumber perdebatan hangat di dunia ilmu hukum (jurisprudential debate), karena menawarkan konsep yang kontroversial dan menyempal dari pakem mazhab hukum yang mapan, mazhab hukum alam. Berbeda dengan mazhab hukum alam yang mengapresiasi relasi hukum dan moral, Austin mengisolasi hukum dari sentuhan moral. Basis filosofis positivisme hukum sebetulnya bisa dilacak sampai ke Hobbes, namun kredit poin lebih banyak diberikan kepada Austin, karena dia dinilai mampu memasarkan dan mempertahankan tesis positivismenya relatif lebih komprehensif dan berani. Austin bukan saja dikenal sebagai figur yang kukuh membela positivisme substantif (substantive positivism) lewat 'command theory' yang mendalilkan bahwa hukum adalah perintah dan 'separation thesis' yang memisahkan hukum dan moral, tapi juga dijuluki sebagai pionir dari positivisme metodologis (methodological positivism). Sebagai tokoh positivisme metodologis, Austin berusaha memberikan panduan kepada para pembelajar ilmu hukum mengenai batas-batas dari ilmu

PADJADJARAN Jurnal IImu Hukum Volume 3 Nomor 2 Tahun 2016 [ISSN 2460-1543] [e-ISSN 2442-9325] 
tersebut. Lewat definisi hukum yang dibuatnya Austin seolah berkata, belajar hukum bukan belajar tentang moralitas. Austin dengan positivismenya memang kontroversial, tapi menantang.

\section{A. Sketsa Biografis}

John Austin lahir di Creeting Mill, Suffolk, Inggris, pada tanggal 3 Maret 1790 dari pasangan Jonathan dan Anne Austin. Ayahnya adalah seorang petani gandum di wilayah selatan Inggris yang merupakan anak tertua dari keluarga petani kelas menengah. Masa kecil Austin adalah permulaan abad ke-19 yang panjang (long nineteenth century), yaitu periode ketika struktur sosial masyarakat Eropa mengalami guncangan hebat yang menembus sampai pada titik fondasinya dan pada saat yang bersamaan revolusi Prancis mengikis habis benteng absolutisme monarki di benua Eropa. ${ }^{1}$

Austin memulai studi hukumnya pada tahun 1812 setelah lima tahun berdinas di militer dan selama tujuh tahun berkarir sebagai praktisi hukum yang diakuinya tidak begitu sukses, karena Austin lebih tertarik pada kajian teori hukum. Sebagai praktisi hukum Austin hanya menyelesaikan beberapa kasus saja dan akhirnya Austin meninggalkan dunia praktisi hukum pada tahun 1825. Austin menikahi Sarah Taylor pada tahun 1820, seorang perempuan cantik, energik, dan cerdas yang dikemudian hari menjadi mitra bahkan sumber inspirasi bagi karya-karya Austin. Perkawinan ini membawa Austin masuk dalam pergaulan dengan lingkar dalam para intelektual tenar London semacam James Mill dan John Stuart Mill dan secara khusus membawa Austin menjadi bagian dari lingkaran utilitarianisme Bentham. Austin memiliki kesan dan perhatian khusus terhadap Bentham, sosok representatif dari utilitarianisme konservatif dan otoritarian. ${ }^{2}$ Meskipun demikian, Austin tidak taklid buta terhadap Bentham, bahkan kerap mengkritik ide-ide Bentham. ${ }^{3}$

Pada tahun 1826 University College London didirikan, Austin diangkat sebagai profesor ilmu hukum dan hukum internasional yang pertama di universitas tersebut. Austin kemudian mempelajari Hukum Romawi dan Hukum Perdata Modern di Jerman selama dua tahun. Dia sangat terpengaruh oleh pemikiran Prof. Thibaut (1772-1840), ahli hukum Jerman yang dikenal sebagai tokoh aliran filsafat (philosophical-school), yang mempertahankan pola pikir hukum alam dengan spirit rasio-

1 Michael Taylor, "John Austin" dalam buku The Dictionary of Nineteenth-Century British Philosophers, yang disusun oleh W. J. Mander (eds), London: Thoemmes Continuum, 2002; Brian Bix, "John Austin", http://plato.stanford.edu/entries/austin-john/; Eira Ruben, "John Austin's Political Pamphlets 1824-1859" dalam buku Perspective in Jurisprudence, yang disusun oleh Elspeth Attwool (eds), Glasgow, 1977, hlm. 20. Lihat juga Wilfrid E. Rumble (eds), Austin: The Province of Jurisprudence Determined, Cambridge: Cambridge University Press, 1995, hlm. viii.

2 Andras Kecskes, "Inside and Outside the Province of Jurisprudence", Rehctstheorie, Vol. 46, 2015, hlm. 466. Wilfrid E. Rumble (ed.), Loc.cit.

3 Rumble, Ibid., hlm. ix 
nalisme moderat. Namun sayang, kedatangannya ke Jerman dianggap prematur, karena perdebatan sengit antara aliran filsafat dan aliran sejarah yang dipelopori oleh Savigny baru saja dimulai. Seandainya datang lebih lambat, Austin dapat menggunakan kompromi-kompromi dalam perdebatan tersebut dalam pengembangan pemikirannya. Jikalau Austin lebih memiliki kesesuaian dengan jalan pikiran Savigny, kemungkinan besar pemikirannya akan lebih banyak diterima, karena pandangan aliran sejarah tampaknya lebih mendekati filosofi dan pola pikir masyarakat Inggris mengenai hukum. ${ }^{4}$

Kuliah-kuliah hukum Austin pada tahun 1828 diikuti oleh banyak tokoh. Tercatat beberapa ilmuwan tenar yang mendatangi kuliah-kuliahnya seperti John Stuart Mill, Sir George Cornwall Lewis, dan Sir Samuel Romily yang dikenal sebagai 'inner circle'-nya Bentham. Tapi Austin kurang berhasil menarik minat mahasiswa untuk mengikuti kuliahnya, sehingga menjadi alasan bagi Austin untuk pensiun pada tahun 1832 dan pada tahun 1834 benar-benar berhenti memberikan kuliah ilmu hukum. Adalah sesuatu yang agak ironis, meskipun Austin dianggap kurang berhasil sebagai dosen ilmu hukum, namun bahan-bahan kuliahnya setelah dibukukan dan salah satunya yang paling penting adalah buku dengan judul The Province of Jurisprudence Determined yang diterbitkan pada tahun 1832 menjadi salah satu rujukan penting dalam perkembangan ilmu hukum di Inggris. ${ }^{5}$

Setelah berhenti sebagai dosen, Austin pernah menjadi anggota Komisi Pembaharuan Hukum Pidana pada tahun 1833, namun dia merasa pendapatnya kurang mendapat dukungan, kemudian dia memutuskan untuk berhenti pada tahun 1836 setelah menandatangani laporan pertama dari dua laporan yang dibuatnya. Pada tahun yang sama Austin diangkat menjadi komisioner untuk urusan Malta. Austin menghabiskan sebagian besar sisa hidupnya di luar Inggris khususnya di Paris sampai tahun 1848. Kemudian kembali ke Inggris dan menetap di Surrey sampai meninggal dunia pada tahun1859.

\section{B. Positivisme Hukum}

Austin dikenal luas sebagai salah tokoh aliran positivisme hukum. Penjelasan secara singkat mengenai pengertian positivisme hukum perlu disampaikan sebagai pengantar untuk menyelami pemikiran hukum Austin. Sebagai sebuah terma generik, positivisme adalah terma yang kabur (vague). Namun secara umum dapat dikatakan bahwa positivisme adalah terma untuk menjelaskan doktrin bahwa pengetahuan manusia itu dibatasi oleh sesuatu yang dapat diamati. Positivisme berakar pada tafsir empirisme yang menganggap bahwa segala sesuatu harus

\footnotetext{
Ibid.

5 Michael Taylor, Loc.cit. Lihat juga Albert Venn Dicey, Lectures on the Relation between Law and Public Opinion in England during the Nineteenth Century, London, 1905, hlm. 410-412.
} 
teramati dan berlandaskan kepada pengalaman. ${ }^{6}$ Secara demikian, positivisme dapat dimaknai sebagai terma yang berkaitan dengan segala sesuatu yang nyata, pasti, dan jelas atau kebalikan dari sesuatu yang bersifat khayal, metafisik, dan tidak bisa dibuktikan secara empiris. ${ }^{7}$

Sebagaimana halnya positivisme, terma positivisme hukum (legal positivism) juga tidak terlepas dari kontroversi. Meskipun demikian, terma ini selalu dihubungkan dengan perkembangan pemikiran hukum di Inggris yang terutama dinisbahkan kepada dua tokoh kenamaannya, yaitu Jeremy Bentham dan John Austin, yang seringkali juga dijuluki sebagai tokoh positivisme hukum klasik. ${ }^{8}$ Sebagai sebuah mazhab pemikiran hukum, positivisme hukum adalah sebuah pendekatan dalam teori hukum mengenai 'posited law' (hukum yang ditetapkan), yaitu hukum itu harus dibuat oleh lembaga pembuat hukum seperti parlemen atau pengadilan. Positivisme hukum menekankan bahwa karena hukum itu dibuat atau ditetapkan (positum), maka hukum harus dipisahkan dari moral dan ide-ide yang memberikan penilaian terhadap aktivitas manusia.

Austin sebagai tokoh positivisme hukum garda depan membedakan antara eksistensi dan substansi hukum di satu pihak dengan nilai-nilai moral, kepatutan (merit) dan ketidakpatutan (demerit) dari substansi hukum di pihak lain. Positivisme hukum tidak mempermasalahkan mengenai baik atau buruk substansi hukum. Yang penting, hukum tersebut dibuat oleh lembaga pembuat hukum, khususnya negara. Dalam positivisme hukum, negara memiliki peran sentral dalam pembuatan hukum.

H.L.A Hart menetapkan lima kriteria pokok untuk mengetahui suatu pemikiran tergolong positivisme hukum, yaitu: ${ }^{9}$

1. That laws are commands of human beings;

2. That there is no necessary connection between law and morals;

3. That the analysis of legal concepts is (i) worth pursuing, (ii) distinct from (thought not hostile to) sociological and historical enquiries by logical and critical evaluation;

4. That a legal system is a 'closed logical system' in which correct decisions may be deduced from predetermined legal rules by logical means alone; dan

5. That moral judgements cannot be established, as statements of fact can, by rational argument, evidence, or proof (this is known as 'non-cognitivism in ethics').

$6 \quad$ "Positivism is rooted in the empiricist interpretation of the scientific revolution", Mark Tebbit, Philosophy of Law: An Introduction, New York: Routledge, 2005, hIm. 15.

7 Widodo Dwi Putro, Kritik Terhadap Paradigma Positivisme Hukum, Yogyakarta: Genta Publishing, hlm 52.

8 Raymond Wacks, Understanding Jurisprudence: An Introduction to Legal Theory, Oxford: Oxford University Press, 2005, hlm. 138.

9 H.L.A. Hart, The Concept of Law, Edited by Joseph Raz, Penelope A. Bulloch, Oxford: Oxford University Press, 2012, hlm. 212. 


\section{Hukum adalah Perintah}

Salah satu tema utama dari pemikiran Austin adalah klaim bahwa "hukum itu adalah perintah penguasa" (law as a command of the sovereign). Dalam kesempatan lain Austin mengatakan, 'law is a command of lawgiver'. Hukum adalah produk kuasa pembuat hukum. Lebih tegasnya, hukum adalah produk dari kekuasaan yang merdeka (unfettered sovereign). 'Perintah' (command) adalah kata kunci dari makna dan esensi hukum menurut Austin. Sehingga bagi Austin hukum yang benar itu tidak lain adalah 'perintah' itu sendiri. "Laws proper, or properly so called, are commands; laws which are not commands, are laws improper, or improperly so called"..$^{10}$ Atas dasar ini, teori hukum Austin seringkali disebut juga sebagai 'command theory' yang ide dasarnya sebetulnya merujuk kepada karakteristik hukum menurut Bentham. ${ }^{11}$ Austin ingin mencari dan menemukan fondasi hukum dengan sesuatu yang nyata (real), dan 'perintah' adalah jawabannya. Perintah dimaknainya sebagai sesuatu yang bersifat imperatif dan disengaja atau dikehendaki yang berasal dari seseorang atau yang ditujukan untuk pihak lainnya untuk bertindak sesuai dengan perintah tersebut.

Menurut Austin, perintah adalah suatu kehendak (desire), tapi berbeda dengan kehendak pada umumnya dan yang membedakannya bukan jenis dari kehendak itu sendiri, melainkan kekuasaan dan tujuan dari pihak yang mengeluarkan perintah tersebut, yaitu memberikan sanksi (to inflict evil or pain) apabila perintah tersebut tidak dilaksanakan atau diabaikan. Secara demikian, perintah yang melahirkan hukum dalam pandangan Austin mesti mengandung kewajiban (duty), karena sanksi hukum lahir disebabkan pengabaian terhadap kewajiban tersebut. Bagaimana relasi antara perintah dan kewajiban digambarkan oleh Austin sebagai berikut: "...command and duty are, therefore, correlative terms: the meaning denoted by each being implied or supposed by the other. Or (changing the expression) wherever a duty lies, a command has been signified; and whenever a command is signified, a duty is imposed". ${ }^{12}$

Perintah agar dapat menjadi hukum harus mengandung tiga elemen, yaitu: wish (kehendak), communication (komunikasi), dan sanction (sanksi). Kehendak atau niat yang dimaksud bukan sekadar niat biasa, melainkan kehendak yang mengarahkan seseorang untuk berperilaku yang tujuannya untuk melakukan sesuatu atau tidak melakukan sesuatu. ${ }^{13}$ Komunikasi yang dimaksud adalah meng-

10 John Austin, The Province of Jusriprudence Determined, edited by Wilfrid E. Rumble, Cambridge: Cambridge University Press, 1995, hlm. 10.

11 Marett Leiboff dan Mark Thomas, Legal Theories in Principle, Sydney: Thomson Lawbook Co, 2004, hlm. 152.

12 John Austin, (edited by Rumble), Op.cit., hlm. 21-22.

13 John Austin, The Province of Jurisprudence Determined, New York: Noonday Press, 1954, First published in 1832, hlm. 13-14. 
komunikasikan kehendak dari pembuat hukum (the wishes of the lawmakers). Kehendak dalam pengertian Austin dapat menjadi 'perintah' hanya apabila dikomunikasikan dengan bahasa atau bentuk komunikasi lainnya yang dapat dipahami oleh masyarakat (the subject of the command behaves). Berbeda dengan Bentham, pandangan Austin tentang sanksi lebih sederhana, karena sanksi sudah melekat di dalam perintah. Menurut Austin, sanksi adalah suatu tindakan yang buruk (an evil) yang dikenakan oleh seseorang atau pihak yang memiliki kehendak (sovereign) terhadap orang/pihak lain yang tindakannya bertentangan dengan kehendak tersebut. Bukan merupakan hal yang penting, apakah kehendak itu diekspresikan dengan perintah yang kasar atau dengan sebuah permohonan yang sopan. Kehendak dapat menjadi perintah apabila didalamnya membawa serta ancaman bahaya (threat of harm)..$^{14}$

Sesuatu yang bukan perintah, bukan hukum. Hanya perintah yang bersifat umum (the quality of generality) yang dianggap sebagai hukum dan perintah yang berasal dari pemegang kuasa adalah hukum yang berlaku (positive laws). Eksistensi sebuah sistem hukum merupakan kombinasi dari kekuasaan yang merdeka dan kepatuhan masyarakat. ${ }^{15}$ Perintah khusus (specific commands) yang dibuat atau dilakukan oleh seorang individu terhadap yang lainnya bukan merupakan hukum. Perintah yang bernilai hukum adalah perintah yang menciptakan kewajiban. ${ }^{16}$ Dengan demikian, Austin tidak menganggap semua bentuk perintah adalah hukum. Perintah yang dapat menjadi dan menciptakan hukum adalah perintah yang diproduksi atau dikeluarkan oleh pihak atau lembaga yang memiliki otoritas, misalnya; raja, ratu, atau parlemen. Lembaga yang memiliki otoritas tersebut oleh Austin disebut dengan istilah 'sovereign' . ${ }^{17}$

\section{Sovereign}

Terma 'sovereign' atau 'sovereignty' memiliki posisi khusus dalam bangunan pemikiran hukum Austin, karena dari sanalah hukum tercipta. Namun, terma 'sovereign' itu sendiri bersifat multi makna dan digunakan untuk area dan kepentingan yang berbeda termasuk dalam bidang hukum. Terma ini biasa digunakan dalam hukum tata negara dan juga hukum internasional yang dalam bahasa Indonesia diterjemahkan menjadi 'daulat' atau 'kedaulatan'. Ketika menjelaskan terma 'sovereign' Austin berangkat dari satu pemahaman bahwa dalam suatu masyarakat terdapat mayoritas rakyat, Austin menyebutnya dengan istilah 'the bulk of people' yang secara sukarela taat (the habit of obedience) kepada pihak yang disepakati memiliki kewenangan atau kekuasaan (the determinate and

\footnotetext{
Ibid., hlm. 14.

Lihat juga Raymond Wacks, Op.cit., hlm. 56-57.

John Austin, Op.cit., hlm. 10.

Marett Leiboff dan Mark Thomas, Op.cit., hlm. 154.
} 
common superior). Pemilik kewenangan atau kekuasaan ini dapat berupa individu, misalnya raja, atau suatu institusi, contohnya parlemen.

Pemilik kuasa tertinggi (superior) menurut Austin tidak dalam posisi untuk mematuhi pemilik kuasa yang setara. 'Sovereign' dapat memerintahkan kepada subjek terperintah untuk melakukan atau tidak melakukan sesuatu, namun 'sovereign' itu sendiri bukan subjek yang dapat atau harus tunduk kepada pihak yang ada diatasnya dalam hierarki sosial dan politik. Relasi di antara keduanya dapat dikatakan sebagai relasi yang bernilai positif (positive mark) untuk yang pertama, sedangkan relasi yang kedua bernilai negatif. Leiboff dan Thomas menggambarkan relasi tersebut dengan sangat baik sebagai berikut: "....obedience flows up from subjects to the sovereign, but not upwards from the sovereign to any higher authority". ${ }^{18}$ Sementara Buckland sebagaimana dikutip oleh Chand mengatakan bahwa, hukum disebut hukum karena dibuat oleh 'sovereign', sedangkan 'sovereign' memiliki kuasa (sovereignty) karena ia membuat hukum. ${ }^{19}$

Posisi 'sovereign' yang tampak 'superior' menjadikannya sebagai entitas kuasa yang tidak bisa dibatasi (illimitable) dan tidak dapat dibagi (indivisible). Dengan karakteristik sebagai entitas yang tidak dapat dibatasi, 'sovereign' tidak bisa dihentikan untuk memproduksi hukum yang diingankan sepanjang hal tersebut ditujukan kepada subjek terperintah bukan kepada entitas kuasa yang setara. Demikian halnya, karena 'sovereign' juga tidak bisa dibagi, maka apabila suatu perintah dikeluarkan oleh 'sovereign' dan mengakibatkan terbaginya supremasi 'sovereign' dan dengan sendirinya perintah tersebut akan berlaku baginya. Hal ini bertentangan dengan fondasi dasar dari 'sovereign' itu sendiri, yaitu tidak bisa menerima perintah dari entitas yang setara. ${ }^{20}$

Konsep 'sovereign' Austin berbeda dengan Bentham yang mengakui adanya batasan (limitable) dan juga terbaginya (divisible) supremasi dari 'sovereign'. Menurut Bentham, pembatasan hukum dapat dikenakan terhadap 'sovereign', yaitu lewat doktrin judicial review. Ide 'sovereign' Austin tampaknya diadaptasi dari model hukum pidana yang rigid, sedangkan Bentham meletakkannya dalam sebuah rekonstruksi yang lebih rasional. ${ }^{21}$ Lebih daripada itu, gagasan Austin sangat dipengaruhi oleh sistem monarki Inggris yang sudah mapan. Parlemen Inggris menetapkan hukum bukan hanya untuk Inggris tapi juga untuk semua koloninya. Oleh karenanya Austin memaknai 'sovereign' sebagai sesuatu yang tidak terbatas dan tidak terbagi.

18 Ibid., hlm. 155.

19 Buckland: "Law is law because it is made by the sovereign. The sovereign is sovereign because he makes the law" dalam buku Modern Jurisprudence, yang disusun oleh Hari Chand, Malaysia: International Law Book Series, 2005, hlm. 75.

20 Marett Leiboff dan Mark Thomas, Op.cit., hlm. 157.

21 Hari Chand, Op.cit, hlm. 77. 
'Sovereign' adalah sesuatu yang stabil sebagaimana halnya monarki Inggris. Dalam situasi dan konteks seperti ini tidak ada ruang bagi masyarakat untuk tidak menaati hukum (disobedience). Ditambah lagi, sejarah hidup Austin adalah periode awal pertumbuhan metode ilmiah. Segala sesuatu akan dikaji dengan pendekatan ilmiah. Sehingga, aspek moral dan agama tidak boleh menyentuhnya termasuk untuk wilayah hukum. Pertimbangan moral akan masuk ketika masyarakat berada dalam bahaya dan inilah yang menjadi raison d'être bagi eksistensi hukum alam. Sedangkan positivisme hukum akan hidup pada sistem politik dan sosial yang stabil. Situasi sosial inilah yang dilihat dan dialami Austin di Inggris ketika itu yang mengilhaminya untuk melahirkan gagasan mengenai 'sovereign' ${ }^{22}$

\section{E. Sanksi}

Austin menempatkan sanksi sebagai salah satu elemen penting dari hukum. Pengertian sanksi harus diletakkan dalam pemaknaan Austin terhadap terma perintah (command). Menurut Austin, dalam terma 'command' terkandung makna sanksi atau keharusan untuk patuh (enforcement of obedience), terkandung juga makna tugas atau kewajiban, dan juga pengertian pemerintah dan yang diperintah (superior and inferior). ${ }^{23}$ Sanksi ditempatkan oleh Austin sebagai bagian tidak terpisah dari perintah, karena ia hadir sebagai akibat tidak terlaksananya perintah. Dengan perkataan lain, perintah dalam pengertian yang sebenarnya harus mengandung sanksi. Dalam konteks ini, Austin menjelaskan pengertian sanksi sebagai berikut:

"The evil which will probably be incurred in case a command be disobeyed or (to use an equivalent expression) in case a duty be broken, is frequently called a sanction, or an enforcement of obedience. Or (varying the phrase) the command or the duty is said to be sanctioned or enforced by the chance of incurring the evil." 24

Sanksi juga seringkali dipahami sebagai hukuman (punishment). Namun menurut Austin, hukuman itu hanya bagian dari sanksi dan dianggap terlalu sempit menyamakan sanksi dengan hukuman. ${ }^{25}$

Beberapa pakar kenamaan seperti Locke dan Bentham menggunakan terma sanksi untuk merujuk kepada kebaikan yang kondisional dan kejahatan yang kondisional. Terma sanksi juga dapat digunakan untuk memaknai 'reward' (penghargaan) dan 'punishment'. Lebih lanjut Bentham menjelaskan bahwa perintah dari 'sovereign' dapat dikualifikasikan sebagai hukum meskipun tidak mengandung sanksi dalam pengertian Austin. Bagi Bentham, hukum itu meliputi

\footnotetext{
Ibid., hlm. 80.

John Austin, (edited by Rumble), Op.cit., hlm. 10.

Ibid., hlm. 22.

$25 \mathrm{lbid}$.
} 
baik hukuman (coercive motives) maupun penghargaan (alluring motives). ${ }^{26}$ Namun menurut Austin, perluasan makna terma sanksi untuk tujuan tersebut dianggap kacau dan mengacaukan makna hakiki dari sanksi, karena 'rewards' terkait dengan tindakan yang bermotifkan untuk memenuhi kehendak pihak yang lain. Apabila hukum hadir dengan tujuan memberikan penghargaan sebagai syarat untuk melakukan suatu perbuatan, maka hakikatnya hukum itu menyediakan hak, bukan membebankan kewajiban. Konsekuensinya, elemen imperatif hukum akan dibebankan kepada pihak yang harus menyediakan penghargaan tersebut. ${ }^{27}$

\section{F. Hukum dan Bukan Hukum}

Berdasarkan ide dasar Austin mengenai 'command' dan 'sovereign', tema pokok yang kemudian harus dibahas adalah apa yang dapat dikualifikasikan sebagai hukum dan yang bukan hukum (non hukum). Austin membedakan antara perintah khusus (particular commands) dan perintah umum (general commands). Tidak setiap perintah dengan sendirinya merupakan hukum. Hanya yang berkategori perintah umum yang dapat membentuk hukum. Perintah yang hanya ditujukan kepada seseorang untuk melakukan sesuatu, tidak dapat dikategorikan sebagai hukum, karena bersifat perintah khusus. Namun, apabila perintah tersebut ditujukan kepada semua orang, maka perintah tersebut disebut sebagai perintah umum dan perintah tersebut merupakan hukum dalam arti yang sebenarnya (law properly so called). ${ }^{28}$

Perintah umum atau Austin menyebutnya sebagai 'law properly so called' terbagi menjadi dua, yaitu hukum Tuhan (divine laws atau the Laws of God) dan hukum buatan manusia (human laws). Meskipun sifat dari hukum Tuhan itu masuk dalam kategori perintah umum, namun perintah tersebut tidak dibuat oleh entitas politik yang berkualifikasi 'sovereign', maka menurut Austin, hukum Tuhan tidak masuk dalam kategori 'law properly so called'. Apakah hukum buatan manusia dapat digolongkan ke dalam kategori hukum dalam arti yang sebenarnya?

Jawabannya tergantung sumber dari mana hukum itu berasal. Hukum buatan manusia yang berasal dari 'sovereign', maka masuk dalam kategori hukum positif (positive law), yaitu hukum yang berisi kehendak atau perintah 'sovereign' yang dinyatakan dalam bentuk-bentuk tertentu dan dilengkapi dengan sanksi. Sementara itu hukum buatan manusia yang bukan berasal dari 'sovereign' tidak merupakan hukum positif, meskipun memiliki karakteristik hukum positif. Jadi bagi Austin, kriteria utama hukum adalah sumber yang mengeluarkannya, yaitu entitas politik yang berkualifikasi 'sovereign' ${ }^{29}$

\footnotetext{
Lihat juga Raymond Wacks, Op.cit., hlm. 63.

John Austin, Op.cit., hlm. 22.

Ibid., hlm. 29-30.

Ibid., hlm. 31. Lihat juga Marett Leiboff dan Mark Thomas, Op.cit., hlm. 158-160.
} 
Klasifikasi hukum selanjutnya dari Austin adalah apa yang dia sebut sebagai 'laws improperly so called' (bukan hukum yang sebenarnya atau bisa juga disebut sebagai bukan hukum). Hukum yang masuk kategori 'laws improperly so called' lahir dari dua proses, yaitu lewat analogi tertutup (close analogy) dan analogi metaforis (slender analogy). Hukum produk analogi tertutup adalah hukum yang lahir dari persepsi subjektif seseorang berupa pendapat atau penilaian bagaimana seharusnya seseorang atau setiap orang berperilaku. Hal seperti ini tidak dapat dikategorikan sebagai hukum, karena tidak berbentuk perintah yang dilengkapi dengan sanksi yang dikeluarkan oleh entitas politik yang berkualifikasi 'sovereign'. ${ }^{30}$ Austin menyebut hukum seperti ini sebagai 'rules of honour' atau 'rules set by gentlemen' yang mencerminkan pendapat yang bersifat temporer mengenai perilaku yang seharusnya, atau disebut juga sebagai 'rules of fashion'.

Menurut Austin, hukum internasional (Austin menyebutnya hukum antar bangsa - law of nations) adalah contoh dari kategori bukan hukum yang sebenarnya, bukan termasuk hukum positif. Bagi Austin, hukum internasional hanyalah pendapat dan ungkapan yang disepakati oleh negara-negara pada waktu tertentu (temporer). Hukum internasional tidak dibuat oleh satu entitas politik internasional (international sovereign) yang memiliki otoritas untuk mengeluarkan perintah-perintah yang mengandung sanksi. Hukum internasional tidak mencerminkan adanya kepatuhan terhadap entitas politik diatasnya yang terpusat (political superior). Bahkan bagi Austin, hukum tata negara pun bukan hukum dalam arti sebenarnya. Alasannya, hukum tata negara secara efektif membatasi kewenangan 'sovereign'. Padahal, menurut Austin, 'sovereign' tidak boleh tunduk kepada entitas politik yang ada diatasnya, termasuk untuk tunduk kepada batasan yang dibuatnya sendiri. Pembatasan terhadap 'sovereign' tidak boleh dilakukan, karena 'sovereign' bersifat illimitable dan indivisible.

Kategori hukum yang sebenarnya bukan hukum juga dihasilkan lewat analogi metaforis (slender analogy), yaitu suatu analogi yang bersifat metaforal bukan literal. Misalnya yang terkait dengan hukum-hukum fisika atau hukum-hukum mengenai perilaku binatang. Meskipun menggunakan terma 'law' tapi hal tersebut bukan hukum sebagaimana yang dipahami sebagai perintah yang diproduksi oleh 'sovereign'. Menurut Austin, "...these so-called laws do not apply to rational beings, but to animals (who lack rasons) or to inanimate objects". ${ }^{31}$

\section{G. Kritik}

Kritik terhadap pemikiran Austin pada umumnya ditujukan kepada teori utamanya tentang hukum yang berbasis kepada perintah (command theory). Ketika Austin

30 Ibid. Marett Leiboff dan Mark Thomas, Op.cit.,, hlm. 160-161.

31 Lihat Marett Leiboff dan Mark Thomas, Ibid., hlm. 161. 
mendefinisikan hukum sebagai perintah, ia memberikan deskripsi formal mengenai hukum dan hal itu tidak salah, tapi tidak cukup memadai untuk menggambarkan hakikat hukum yang sebenarnya. Austin tidak memasuki realitas hukum yang sebenarnya, hanya memperkenalkan bagian luar dari hukum, yaitu institusi dan proses formal bagaimana hukum tercipta. Austin mengabaikan aspek-aspek lain yang terkait erat dengan hukum, bagaimana hukum itu muncul dan bagaimana hukum mempengaruhi atau dipengaruhi oleh masyakarat.

Austin menjauhkan nilai dari hukum sehingga menjadikan hukum itu kering dan kaku, karena berwujud tanpa nilai. Hukum tidak mampu menyediakan kekuatan positif untuk mempromosikan nilai-nilai, sedangkan nilai-nilai tersebut merupakan bagian terpenting dari hukum. Menjadikan hukum hanya semata produk dari entitas politik yang bernama 'sovereign', menjadikan hukum bebas dari keterlibatan disiplin pertimbangan ilmu lain yang seharusnya berkontribusi seperti sosiologi, antropologi, ekonomi, termasuk juga politik.

Austin menjadikan sanksi sebagai salah satu elemen utama dari hukum. Konsep ini dikritik, karena sebetulnya aspirasi publik dapat menjadi sanksi hukum yang efektif. Dalam masyarakat modern, hukum dibentuk oleh perwakilan masyarakat bukan oleh kehendak 'sovereign' (penguasa).

Kritik lainnya juga ditujukan kepada konsep 'sovereign' yang cenderung absolut, karena menjadikannya sebagai entitas politik superior yang men-subordinasikan entitas politik lainnya. Konsep Austin ini bukan saja menyimpang bahkan melawan prinsip demokrasi yang justru menempatkan supremasi suara rakyat di atas entitas politik sebagaimana dipahami oleh Austin. Singkatnya, konsep 'sovereign' Austin menihilkan aspirasi publik.

Teori 'sovereign' Austin yang berwajah absolut yang diyakini dipengaruhi oleh situasi sosial politik ketika dia hidup yaitu monarki Inggris yang stabil, tidak sepenuhnya benar. Faktanya, monarki tidak sepenuhnya absolut. Mereka juga tunduk kepada etika dan moral, tata laku yang disepakati (code of conduct), dan hukum-hukum agama. Apabila mereka melanggarnya, monarki tersebut berada dalam bahaya karena memancing terjadinya revolusi (people power).

Para pengeritik Austin menyajikan fakta yang mencengangkan karena ternyata teori Austin ini tidak sepenuhnya berlaku di Eropa tempat di mana Austin menggali teori tersebut. Austin mengklaim bahwa raja dan parlemen adalah 'sovereign' di Inggris. Klaim ini tidak sepenuhnya benar, sebab faktanya raja dan parlemen tidak sepenuhnya absolut. Mereka juga harus memperhatikan dan mempertimbangkan aspirasi publik. Realitasnya, aspirasi publik adalah sumber kekuasaan utama. Adalah aspirasi publik yang memberikan kekuatan kepada parlemen. Atas dasar ini mengapa diadakan pemilu setiap lima tahun sekali untuk memilih anggota Majelis Rendah (House of Commons). Majelis Tinggi (House of Lords) tidak akan efektif tanpa Majelis Rendah. 
Singkatnya, positivime hukum Austin mengandung tiga kelemahan utama, yaitu: pertama, Austin membuat pengertian hukum yang kurang lengkap, karena mengabaikan elemen penting dari hukum yang bukan merupakan perintah atau pun sanksi, yaitu dimensi etik dan moral. Kedua, model pemahaman hukum Austin melupakan pertimbangan bagaimana hukum digunakan atau beroperasi di masyarakat, yaitu pandangan masyarakat itu sendiri terhadap hukum, atau meminjam terma yang digunakan Hart sebagai 'external view of law'. Yang lebih fatal, Austin keliru mengidentifikasi sumber ketaatan individu terhadap hukum yang semata-mata karena adanya 'the habit of obedience' yang hakikatnya tidak lain adalah pemaksaan. Secara demikian, positivisme hukum Austin esensinya adalah pemikiran yang berbasis kepada ideologi otoritarian. Dan terakhir, konsep Austin tentang relasi 'sovereign' dan 'command' bertentangan dengan realitas berikut: sovereign tidak sepenuhnya dapat diidentifikasi dengan menggunakan parameter yang digunakan Austin, hukum juga bisa dilahirkan dari sumber selain 'sovereign' dan ia sebetulnya tidak memiliki kewenangan legislasi tidak terbatas (unlimited legislative power) dalam suatu negara modern.

Atip Latipulhayat 